\title{
'Man Alone and Men Together: Maurice Shadbolt, William Malone and Chunuk Bair'1
}

\section{JAMES BENNETT}

It is hard to find a discussion of New Zealand culture in which John Mulgan's novel Man Alone (1939) does not figure... Actually, few of these figures are literally men alone, as that thematic is joined to a second great Australasian motif, that of mateship.' ${ }^{2}$

\section{A man alone could not survive. ${ }^{3}$}

This article will consider the motivation behind, and timing of, Maurice Shadbolt's interventions as a writer between 1982 and 1988 to determine the extent to which cultural nationalist interpretations of Gallipoli resonated in that decade and how they came about. My argument will pivot around Shadbolt's powerful 1982 stage play (Once on Chunuk Bair), subsequently adapted as a low budget feature film (Chunuk Bair), and his later collection of oral histories. ${ }^{4}$ As Annabel Cooper points out, although a dramatic production Once on Chunuk Bair is a very conscious attempt to anchor a creative piece in history by drawing extensively on the work of historians to buttress the veracity of its interpretation of the event. ${ }^{5}$ To develop this line of argument further, Charlotte Caning has conceptualized performance on stage as a site for negotiation of the meaning of history by deliberately blurring the boundaries between historiography and dramaturgy. ${ }^{6}$ Although my principal cultural interest lies in history through film, the centrality of Shadbolt and his stage play to the Gallipoli debate in New Zealand necessarily broadens the scope of my discussion on cultural forms to include relevant stage plays as a supplementary interest to fiction feature films. The entwinement of New Zealand and Australian history on the Gallipoli peninsula in 1915 through the integrated command structure as well as interwoven historiographical narratives also means that any analysis of this debate will benefit from transnational and comparative approaches. ${ }^{7}$ Accordingly, the article will also make strategic reference to the most influential contemporaneous Australian cultural nationalist text, Peter Weir's seminal 1981 feature film Gallipoli, to throw the particularity of New Zealand political and cultural circumstances of that era into sharper relief. ${ }^{8}$ As film - and theatre - is a cultural artefact of the period of its production, the discussion will alternate between two pasts, that is, the era of their production - the 1980s - and the moment in time that they represent artistically - 1915.

Gallipoli is surely one of the most well traversed paths in Australian historiography, and Anzac continues to occupy a dominant cultural space on both sides of the Tasman (especially Australia), resuscitated and repackaged in the late-twentieth-century for a new generation that in turn has embraced the tradition with gusto. ${ }^{9}$ Indeed, such is the potency and reach of Anzac that it functions as a white Australian creation myth, one whose commemorative culture has shifted away from its British Empire roots to an 'ahistorical celebration' of men who fell for the nation. ${ }^{10}$ Yet the simplicity of dominant narratives embedded in popular texts belies the striking complexity of the entire campaign and, more particularly, the August Offensive. This is the moment in the campaign that Shadbolt - and Weir - chose to pivot their creative work around; it is also a moment that begs further historiographical scrutiny.

The entwinement and dissemination of New Zealand and Australian narratives in relation to understandings of 1915 - especially the August Offensive - is a useful departure point for this discussion. The seminal force shaping Australian narratives was of course C.E.W. (Charles) Bean, war correspondent and later author of the impressive multi-volume Official History series. Bean has been criticized by many contemporary Australian historians for promoting a very selective interpretation of the Australian digger that filters out negative 
traits and presents him in a highly favourable light as the successor to the Australian bushman with all of the virtues invested in that national archetype. ${ }^{11}$ Yet, Bean's work has also been seen as quite revolutionary in the sense that his are bottom-up histories reflecting his time in the trenches on the frontline. Bean in turn was enormously influential in shaping the work of historians Bill Gammage (The Broken Years, 1974) and Patsy Adam-Smith (The Anzacs, 1991), all of whose work emphasizes the individual. ${ }^{12}$ Similarly, Weir and his screenwriter David Williamson were influenced by Bean's narrative and by Gammage as the film's historical consultant. ${ }^{13}$ Jenny Macleod has also made the cogent observation that revitalization of Anzac in Australia and the strength of emotional engagement with that tradition is in no small measure due to the intervention of journalists - above all Jonathan King and Les Carlyon - who have produced a number of popular histories. ${ }^{14}$

In contrast, New Zealand's war correspondent, Malcolm Ross, who took up duties in May 1915, was considered to lack the technical understanding to undertake the task of writing the official war histories and was therefore passed over in favour of New Zealand field officers. Their histories were produced under a tight censorship regime and were far less effective in serving New Zealanders than were Bean's in the Australian context. ${ }^{15}$ Writing in 1979, Bill Gammage argued that unlike Australia, New Zealand lacked a distinguishing national tradition about Anzac with no national shrine the equivalent of the Australian War Memorial. However, Gammage's argument oversimplifies the distinctions. As in Australia, New Zealand had a pioneer myth and the record of Kiwi soldiers at war upheld that tradition. That the myth was essentially conservative in substance can be seen in the frequent claim to New Zealand soldiers in the Great War as the 'gentlemen of the bush'. ${ }^{16}$ Second, New Zealand also has a Gallipoli tradition albeit one that would come to incorporate some Australian borrowings including introduction of the dawn service in $1939 .{ }^{17}$ It is comprehensible that Australia, the more senior Dominion whose forces far outnumbered the New Zealanders in the campaign, would assert more stridently their claim to Anzac and Gallipoli as a crucible of nationhood. To some extent the effect has been to pre-empt New Zealand claims to Anzac as a core national identity. It is also the case that Gammage's analysis overlooks popular usage of 'Anzac' in Australia; namely, its co-option as short-hand for all things Australian, maintaining a silence in regard to the 'NZ' embedded in the acronym. ${ }^{18}$

Until publication of Christopher Pugsley's groundbreaking text on Gallipoli in 1984 (Gallipoli: the New Zealand Story), Anzacs with the lemon squeezer hats lacked a comprehensive and nuanced history of their own that documented, without fear or favour, the role of the New Zealand Infantry Brigade in the campaign. ${ }^{19}$ New Zealanders would also feature in other accounts such as Bean's but only in a fragmented sense. And much later - at a popular level - in the absence of an equivalent New Zealand screen text, the many rescreenings of Weir's film in New Zealand also influenced popular understandings of the campaign on that side of the Tasman; ironically, Weir's depiction of events in early August 1915 managed to airbrush out Kiwis in an operation where New Zealand advances on Chunuk Bair were coordinated closely with the Australian diversion at the Nek rather than with the falsely contextualized Suvla Bay landings emphasized in Weir's representation. ${ }^{20}$

Through the recovery of veterans' voices, several New Zealand historians - notably Jock Phillips and Nicholas Boyack - have pointed to a clear bifurcation in New Zealand Great War narratives, namely, the hegemonic top-down official narratives (inscribed in the official published histories and on war memorials) and the unofficial or counter-narrative version that emerges so strongly in soldiers' diaries and letters. ${ }^{21}$ This is not unlike the dialectic of disparate but sometimes intersecting traditions in Australia, that is, the Australian official conservative Anzac legend versus unofficial digger folklore. ${ }^{22}$ Shadbolt's Voices of Gallipoli contains a sample of this counter-narrative. One of the striking threads running through these interviews is a bitterly critical tone that condemns, in forceful terms, the failure of leadership 
and strategy throughout the campaign. There is little doubt that New Zealand politicians of the day like Australian-born Defence Minister, Sir James Allen, were well aware how Gallipoli would be read by future historians. ${ }^{23}$ However, veterans' voices were suppressed by dominant official narratives that overwrote a sense of betrayal at the hands of British High Command. $^{24}$

Contrasting trans-Tasman attitudes to Churchill, first Lord of the Admiralty and one of the architects of the Dardanelles strategy, is instructive. Boyack, for instance, has shown that assessments of Churchill by New Zealand Anzacs failed to percolate through to the general population, and this only increased the bitterness of surviving men. Australian views reinforced by a traditional lack of sympathy for imperial Britain from the Irish diaspora and reflected in the tradition of the radical Bulletin newspaper - were similar in character; though the place of Churchill in Australian public memory is more complex and problematic, especially in the light of his role as wartime leader of Britain in the 1940s. Joy Damousi has highlighted paradoxical Australian narratives of Churchill. The official version lauded him as wartime hero, genius and saviour. This perspective ran in tandem with a widely disseminated counterview of Churchill as the bungler of the Gallipoli campaign who abandoned Australians in 1942 and opposed the return of Australian troops from the Mediterranean at a critical moment in the defence of their homeland. Tellingly, the 'widely popularised countermyth' of Churchill, Britain and the Empire at war would later provide sustenance for the work of screenwriter David Williamson, historian David Day (and others), as well as the political rhetoric of Prime Minister Paul Keating in the 1990s. ${ }^{25}$ More broadly, this process underlines the trans-Tasman disjunction on how the campaign came to be interpreted and remembered. ${ }^{26}$

There are two ways of thinking about this. On the one hand, New Zealand journalist and author Graeme Hunt has argued from a nationalist perspective that New Zealand was slow to come to terms with its past - at least this episode in its past - when most Australians, historians included, had come to the conclusion before the Second World War that it was the folly of British High Command that caused such a monumental disaster. ${ }^{27}$ Hunt's argument, though, oversimplifies the nature of Allied failings and ignores, for example, the fact that Australian commanders were very good at killing their own troops, and that some New Zealand and Australian officers were poor leaders or, as in the case of the New Zealand-born imperial officer, Brigadier General Francis Johnston, simply unfit to command. ${ }^{28}$ As James Belich has observed, New Zealand civil and military leaders were relatively ineffectual in shielding their men from the harsh reality of the British military code in what amounted to a 'slaughter system'. 29

The other way to read contrasting New Zealand and Australian interpretations of the campaign would be - to follow the argument of Pugsley - that until relatively recently there has been a striking imbalance in much of the Australian historiography on Anzacs and an excessive emphasis on the cult of the hero. ${ }^{30}$ The almost universal appeal of the Australian bush myth in First World War literature is critical to understanding the dominance of heroicromantic narratives in the Australian Anzac tradition. Whilst it is quite true that a New Zealand rural mythology also existed, as observed earlier the pre-eminence of the Australian bushman in national status and iconography did not find a direct parallel in New Zealand. This literary nationalist tradition that big noted Australian military prowess had its origins in the pre-war era and was given significant impetus by Bean and his war contemporaries. ${ }^{31}$ New Zealanders tend to be much more cautious in using heroic discourse; the traditional emphasis has instead been on the fallen, a practice mirrored in many of the nation's memorials to the 1914-18 war which can be interpreted as a form of 'surrogate tombstone'. ${ }^{32}$ Colonel William George Malone, leader of the ill-fated Wellington battalion on a day of carnage on Chunuk Bair, is exceptional: he stands out as a successful leader and the resolute 
hero who fell in a desperate defence of the highest point in the Allied assault on the Sari Bair range. Unusually for a New Zealand officer, Malone has been a significant subject of attention by Australian military historians especially in the recent past: John Crawford for instance notes 20 references to Malone in Les Carlyon's popular book on Gallipoli. ${ }^{33}$

The interest of historians and creative artists in 1915 and its broader significance to New Zealand society reignited passionately in the early 1980s after a long decline in the tradition of Anzac dating back to the 1960s and the divisive backdrop of social and political dissent in the Vietnam War era. Maurice Shadbolt recognized that the 'old mythology of Gallipoli' was moribund and that the tradition needed to be re-examined 'in a fresh, human and very vivid light'. His work in collaboration with Christopher Pugsley led him to the conviction that there was a firm basis for revitalizing public memory of the event. ${ }^{34} \mathrm{~A}$ shift was underway on the other side of the Tasman around the same time where cultural producer Peter Weir was stirred to make his landmark feature film as a reaction against a tradition of Anzac shrouded in the rituals of Empire and Britishness that had so disaffected him and many of his contemporaries. This process helps to explain the key traits of cultural nationalism and antiBritishness embedded in Weir's film in contradistinction to an earlier era and an epochdefining film in Charles Chauvel's 1940 feature Forty Thousand Horsemen, one that showed 'a jocular though not anti-British attitude to the English'. 35

Curran and Ward have mapped out the transition of Australia to a post-imperial nation, a phenomenon that also took root in other British world communities including New Zealand. Their particular contribution is to identify the 'new nationalism' of the 1960s and 1970s as a critical phase in the transition process, one that was frequently beset by vacillation and confusion, not because there was no popular desire to replace the old imperial symbols and structures but on account of the paucity of 'viable, popularly sustainable alternatives'. ${ }^{36}$ This reflected the climate of uncertainty about precisely how to fill the void of British global decolonization. The nadir of Anzac day in the 1960s was tied to the perception of a martial event with a commemorative culture that had dramatically narrowed in its popular appeal, too much so for it to any longer constitute a genuine national day. This divided community response to Anzac Day during the 1960s and 1970s' hiatus was captured effectively in Australian playwright Alan Seymour's dramatic stage play, The One Day of the Year (1961). Significantly, there was almost no support in this period for the view that Anzac Day could be a plausible conduit for the new nationalism. ${ }^{37}$

The seeds of New Zealand's resolute political and cultural nationalism of the 1980s were sown in the previous two decades. Belich's now familiar conceptual apparatus of 'decolonisation', a period that can be narrowly defined from 1973 to 1985 , is a useful means of apprehending a series of very significant economic and social shifts in the structure of latetwentieth-century New Zealand society. ${ }^{38}$ Of all the Dominions, none had been so intimately tied to Britain in both trade and sentiment as New Zealand. This tightening of relations (or 'recolonial' bonds in the style of James Belich) between New Zealand and Britain, entrenched in the late-nineteenth-century, began to loosen perceptibly in the 1970s and the intensity of these bonds was matched by the trauma that attended their decoupling. ${ }^{39}$ The year 1973, when Britain gained formal entry to the European Economic Community (EEC), makes a symbolic marker of the process (as was the announcement of Britain's withdrawal east of Suez by 1970-71), although as Belich observes, this had been prefigured by developments in the 1960s. ${ }^{40}$ Robert Muldoon's stewardship of the country in the critical years from 1975 to 1984 witnessed a King Canute-like attempt to hold back an irresistible tide of change; to some extent this only masked the decolonial metamorphosis that was in full swing by the time Muldoon was eventually defeated in 1984 by David Lange's fourth Labour government. 
While Australia's experience of Britain's retreat from a global reach was less traumatic than was New Zealand's and some other parts of the former Empire, Curran and Ward observe that 'the fundamental dynamics were remarkably similar'. ${ }^{41}$ Protracted British negotiations in the early 1960s over EEC membership elicited some highly emotional impulses from Australian leaders of the day, and government and media made known their displeasure at the 1962 Commonwealth Immigrants Act that unravelled the traditional principle of free entry into Britain. However, there was little sense of 'material hardship' in Australian attitudes to post-imperial Britain and its lurch toward Europe by the early 1970s, and feelings of abandonment dissipated more quickly than in New Zealand. ${ }^{42}$

Stuart Murray and Ian Conrich have noted a connection between decolonization and the transition to cultural independence in New Zealand beginning in the $1970 \mathrm{~s}^{43}$ The renaissance of a home-grown film industry from 1977 is one of the markers of this transition. As in Australia, the British and American imported product dominated the big screen in the postwar years. Local productions were few in number and the fragile local industry struggled to find investors and audiences. An important component of the cultural renaissance on the big screen lay in its capacity to present 'our own image'. This was encouraged by the formation of respective film commissions in the 1970s - initially in 1970 in Australia and 1978 in New Zealand - to support the growth of indigenous film production along with significant encouragement to investors in the local product through incentives built into the taxation system. $^{44}$

These surface level commonalities between the two settler societies should not obscure some fundamental differences between them in an era of decolonization and a shift toward cultural independence. First, whereas a number of key works of Australian film and television in the revival period centred on Australians in overseas wars (especially the First World War), one struggles to think of equivalent subject matter in New Zealand cinema. A foundation concern of that industry rested on relations between colonizer and colonized, a lineage that can be traced back to the 'father' of New Zealand cinema, Rudall Hayward, and his groundbreaking epics on the New Zealand Wars from the 1920s. Much New Zealand cinema of the late 1970s and early 1980s echoed anxieties in relation to the nation's unfinished colonial business - a subject barely touched on by Australian filmmakers of the day. ${ }^{45}$ At the same time, retaining some emphasis in cultural forms on the First World War predicated on the fiction of Māori equality through soldier citizenship and unity of the two races at war against a common external enemy, would provide a soothing narrative and another technique for occluding an uneasy and unsettled colonial past. ${ }^{46}$

Furthermore, whereas Indigenous Australia was still, at best, peripheral to the consciousness of most white Australians, the 1970s marked the beginnings of a political and cultural renaissance among Māori that would later be reflected on the big screen by Māori film makers. Murray notes the coincidence of this shift toward cultural independence and a frequent unease in articulations of the national imaginary that partly turned on scrutiny of Pākehā culture and questions about legitimacy of the foundations of Aotearoa New Zealand as a settler society. ${ }^{47}$ This interrogation of the national spirit in a decolonizing era is perhaps nowhere better crystallized than in Mereta Mita's activist feature length documentary of the 1981 Springbok rugby tour, an event that was marked by greater civil conflict than at any time in the nation's history since the Great Strike of 1913. The context of the tour was a growing coalescence between the Māori renaissance and 'an emergent middle-class Pākehā political consciousness'. By the time of the tour the tiny social movements of the 1960s had broadened their support base substantially; moreover, the causes they pursued - including opposition to the tour and to nuclear weapons - had become interwoven in complex ways with nationalism. ${ }^{48}$ 
Significantly, Mita's hard hitting cinéma-vérité documentary makes an explicit link between the racism of apartheid South Africa and racism at home. Maurice Shadbolt was active in anti-tour protests and at least one scholar has interpreted his play, her criticisms of it notwithstanding, as a possible 'gesture of reunification' in the wake of these serious divisions. ${ }^{49}$ The link between solider citizenship of the Māori Battalion and colonial warfare is explicitly referenced in Shadbolt's stage play through the character of Otaki George, a descendant of Te Rauparaha, leader of the Ngāti Toa tribe renowned for their role in the Musket Wars of the early-nineteenth-century. Otaki George is deployed to underscore the superficiality of biculturalism. In so doing, Shadbolt calls up an identity based on a common Māori-Pākehā mythology. ${ }^{50}$

By contrast, Weir's uncritical re-presentation of a classic version of the Anzac Legend embeds egalitarianism (and therefore unity) whilst effacing Aboriginal presence in the national story both at home and abroad. ${ }^{51}$ Moreover, the film's success at the box office in a decade that represented the high water mark of celluloid Anzac productions including the television mini-series Anzacs (1985) and The Lighthorsemen (1987), demonstrated aptly how unvarnished and insular nationalist sentiment and mythology could resonate with a popular audience. ${ }^{52}$ In that sense Shadbolt's stage play and Weir's film mirror strongly divergent national preoccupations with history and culture in the 1980s: one acknowledged colonial conflict and the relationship between two peoples in the founding of a nation while the other played up the bush as central to the national imaginary, in the process undergirding the historical narrative of terra nullius. Ann Curthoys has pointed to a number of rival nonAboriginal victim narratives in Australian popular historical mythology, foremost among which is the Gallipoli campaign. As she suggests, these stories of the white settler as victim militate against overt recognition and awareness of a colonial past, and they in turn implicate the nature of 'white racial discourse'. 53

In truth, Shadbolt was not the first New Zealand creative artist to take up Gallipoli as subject matter. Playwright, filmmaker and cultural activist Paul Maunder formed the avantgarde theatre ensemble Amamus in 1971 in Wellington. Maunder and Amamus were adherents of Polish experimental theatre director and innovator, Jerzy Grotowski and their one act play, Gallipolli - An Evocation, first performed in September 1974, became almost synonymous with the life of the theatre company. ${ }^{54}$ A spartan production featuring a combined male and female cast that spanned a mere 45 minutes, Gallipoli was staged inside a square made by walls of white calico making use of a single prop - a .303 rifle. The play was performed more frequently than any other Amamus work both in New Zealand and abroad where it was brought to the stage in London and four centres in Poland including Wroclaw, home of Grotowski's Theatre Laboratory. Unlike the 1980s cultural nationalist texts at the core of this paper, the radical Maunder-Amamus stage-play contests the status of Gallipoli as the birthplace of the (new) masculinized nation, an idea long established in Australian historiography albeit less stridently so in the New Zealand case where there was no equivalent of the radical nationalist Bulletin newspaper with its propagation of bushman masculinities and nationhood. ${ }^{55}$ Questioning of this entwinement is exemplified in the Ottoman soldiers' chorus at the beginning of the play, reprised at the end, that is, 'A Kiwi. A peasant. A barbarian. A child. ${ }^{56}$ In other words, Kiwi is analogous to a colony clinging to dependendence on its mother country. As in an earlier Amamus play, one character, in this case a digger called simply 'Kiwi', is scapegoated. Kiwi charges at the Ottoman enemy and is shot dead. The remainder of the cast, who initially play the role of Ottoman soldiers, turn Kiwi over and summon up the dead to uncover the spirit of the departed Kiwi. This involves examining a series of relationships between Kiwi and his various contemporaries, interspersed with periodic returns to Ottoman forces on the battlefield, producing a complex and very layered piece of theatre. The dynamic of audience relationship was critical to the 
impact of the play; the ensemble did succeed in creating an impact, although the play drew a divided critical response. ${ }^{57}$

The 1980s marked a shift in novelist Maurice Shadbolt's oeuvre towards the use of New Zealand military history as a vehicle for his writing projects, beginning with a Gallipoli dimension in the 1980 novel, The Lovelock Version, his only play, Once on Chunuk Bair (1982) and Voices of Gallipoli, published in 1988, a non-fiction work that included interviews with a dozen veterans of the campaign. ${ }^{58}$ In the last mentioned work Shadbolt recounts the profound emotional experience in 1977 of visiting the Gallipoli peninsula and a classical theatre in nearby ancient Troy, site of Homeric myth making. What struck him was the asymmetry between the significance of Anzac day on the calendar and the absence of major artistic forms in 'national cultural life' whether poetry, music, literature or paintings. Shadbolt wanted a play that encapsulated the New Zealand experience in one day. 8 August 1915, when Kiwi soldiers briefly seized Chunuk Bair, the high point of the Sari Bair range, from Ottoman forces would be that day: one that had long since been erased from national consciousness through a collective amnesia. His intention in writing a play was to create a 'living memorial' to the fallen New Zealand Anzacs at Gallipoli, framing his intention in very similar terms to Peter Weir who was determined to create a 'celluloid memorial' to slaughtered Anzacs. ${ }^{59}$ The play's dramatic arc - following the format of a classical tragedy in its unity of time, place and action - would provide a catharsis to 'let the dead go'. ${ }^{60}$

Shadbolt's play also sought to rehabilitate William Malone, an outstanding leader and exceptional New Zealander; the man whose reputation had been unfairly sullied by his malign commanding officers, Brigade Major and later Colonel, A.C. Temperley and Brigadier General Francis Johnston. ${ }^{61}$ The discrediting of Malone owes much to the voice of his surviving superior officer, Temperley, whose version of events between 6 and 10 August was essentially accepted at the time by his superiors, Godley and Hamilton. ${ }^{62}$ On the request of Charles Bean, Temperley gave the Australian war correspondent a briefing on the narrative of the New Zealand Brigade in the battle for Chunuk Bair in late 1918 or early 1919, and then developed that account in the early $1920 \mathrm{~s} .{ }^{63}$ In this narrative Temperley cast aspersions on Malone's abilities as a military commander and, more critically, condemned the key decision of the Wellington Battalion commander to site trenches on the reverse (rather than the forward) slope of the ridge when seizing the summit on 8 August, essentially claiming that this action had fatally compromised the ability of Allied forces to defend the heights of Sari Bair. ${ }^{64}$ Others present on Chunuk Bair at the time as well as military historians have rebutted Temperley's contentions; however, the Englishman's perspective became ingrained in key historical narratives of the New Zealand Brigade, including the work of Bean and John North, in the process besmirching Malone's name for the best part of a century. ${ }^{65}$ Fred Waite's text The New Zealanders at Gallipoli, part of the popular history series on New Zealand in World War One, mentions Malone's death in passing, but has nothing to say about the circumstances that led to this moment. ${ }^{66}$ As John Crawford has noted, the controversies surrounding Malone and the battle for Chunuk Bair (as well as its defence) long eclipsed the achievements of the Wellington battalion and its leadership. ${ }^{67}$ In 1965 English historian Robert Rhodes James was the first to refute the claims of Hamilton, Temperley and others in relation to Malone's mistaken strategy in siting trenches on Chunuk Bair; until publication of Pugsley's 1984 book on New Zealanders at Gallipoli, Malone's actions were not widely understood. ${ }^{68}$ That process of growing awareness was further supported by the publication of Shadbolt's play and release of the subsequent film adaptation. ${ }^{69}$

One of the most revealing aspects of Temperley's narrative is his silence on Malone's confrontation with himself and Johnston on the morning of 7 August. This followed the critical mistake of Johnston in delaying the advance of the New Zealand Brigade on Chunuk Bair early that morning - thus obliterating the critical element of synchronicity required to 
coordinate their attack with the left assault column and the Australian Light Horse feint at the Nek, immortalized in Weir's film. ${ }^{70}$ Malone had already witnessed the slaughter of several hundred men in the Auckland Battalion, was aware of Johnston's condition and showed a rare strength of character in this campaign to refuse his superior's order (in turn, acting on orders from the remote and ineffectual General Alexander Godley) to attack up hill in broad daylight without artillery or machine gun support. ${ }^{71}$ Malone's confrontation with 'two British officers' (almost certainly Johnston and Temperley) was corroborated by several men and one, Corporal Charles Clark, overheard Malone say: 'I will take the risk and my punishment. These men are not going until I order them to go. I'm not going to send them over to commit suicide. ${ }^{72}$ Malone held the line in his insistence that the Wellingtons would advance from the Apex to capture Chunuk Bair before dawn the following morning. Whilst a disciplinarian and fervent imperialist who put great emphasis on duty and work and a leader who demanded the very highest standards from his men, Malone's response to his superiors at this tense moment is evidence of his forceful character, fair mindedness and high regard for the welfare of the men who served under him. ${ }^{73}$ And while a devout Catholic of Anglo-Irish heritage who was critical of British leadership in the campaign, he saw himself and his men in the revered tradition of British military heroism; indeed, he could imagine 'no better death' than the one fate dealt him. ${ }^{74}$

A recurring motif that emerges from veteran interviewees in Voices of Gallipoli is the strong conviction that Gallipoli marked a decisive turning point for New Zealand: no longer would there be an unquestioning subservience to Empire. This is the strident voice that the writer aligns himself with and enacts in his postcolonial text for the stage. Shadbolt also identifies closely with William Malone and his response to Australian comrades. In deference to the wishes of his family, Malone is not a character in the stage play, but elements of him and several others form the composite character of Colonel Connolly whose love of country (rather than the love for his spouse documented in the Malone diaries and letters) is foregrounded. ${ }^{75}$ Whereas most New Zealand soldiers underwent a transformation in the way they viewed their Australian counterparts between training in Egypt and fighting side by side on the slopes of Gallipoli, Malone was unusual insofar as he retained significant doubts about the quality of Australian diggers even after April $1915 .^{76}$ The commander of the Wellingtons also continued to be concerned about the occlusion of a distinctive New Zealand identity through deployment of the term 'Australasian' and the merging of Australians with New Zealanders in a joint -New Zealand-Australian Division. ${ }^{77}$ Shadbolt not only airbrushes out other Allied formations (notably $7^{\text {th }}$ Gloucester and $8^{\text {th }}$ Welch battalions), but also employs the following dialogue as a corrective to the numerically superior Australians who are perceived by Malone to threaten the distinctive achievements of New Zealand units:

BASSETT: General Sir Ian Hamilton regrets that thus far the offensive has failed to take Achi Baba or Koja Chemen Tepe, but he rejoices in the shining triumph upon Chunuk Bair by - I'm sorry, sir, you aren't going to like this.

CONNOLLY: Go on.

BASSETT: By the magnificent Australians ...

CONNOLLY: The what? The who?

BASSETT (apologetic): By the Australians, sir ... (Weaker) The - magnificent Australians.

CONNOLLY: What Australians? Where?

BASSETT: He doesn't seem to know it's New Zealand up here, sir. ${ }^{78}$

Speaking on an ABC Four Corners report in 2008 about memory, history and Allied involvement on the Western front, Professor Gary Sheffield of Birmingham University made 
the significant point that New Zealand has been one of the losers in projecting its voice forward in the battle for history and memory. ${ }^{79}$ Shadbolt was all too aware of this. In that sense it is worth considering for a moment his motivation for the Voices of Gallipoli project, which came some years after the play. In an interesting synchronicity, Shadbolt and military historian Christopher Pugsley met while each was working on their respective project in the early 1980s - Pugsley on his history of New Zealand's Gallipoli experience and Shadbolt on the play. The latter was approached by Allan Martin, then Director-General of Television New Zealand, to play a lead role in the production of a TV documentary on the campaign. Asked to script it, Shadbolt declined, but he agreed to interview veterans if he could work in association with Pugsley. The host of the series turned out to be ex-General Sir Leonard Thornton and the jarring of his approach with Shadbolt's soon surfaced. Thornton envisioned the documentary series as a 'martial saga', thereby denying the tragic human dimension that Shadbolt saw as so central to the story he was trying to convey. Thornton also questioned not entirely without cause - the reliability of some of the old veterans and their memories. ${ }^{80}$ The force of Thornton's personality ensured that the series bore his imprimatur, the final cut ignoring the Pugsley-Shadbolt script. For Shadbolt, this was just one more cynical overwriting of the veteran voice, and a refusal to allow New Zealanders, in his own words, 'a clear-eyed confrontation with their past'. ${ }^{81}$ The experience left Shadbolt feeling enormously frustrated and one that he saw as largely a 'wasted opportunity' but for valuable interviews with the aged veterans, material that would would later form the core of his non-fiction book. ${ }^{82}$

Before assessing the timing of Shadbolt's key literary work on Gallipoli - Once on Chunuk Bair - I want to first consider its ideological import, beginning with an assessment of Peter Weir's parallel text. Gallipoli is perhaps best seen as a visual exemplification of the Anzac Legend with its emphasis on mateship, sport, landscape, the virtual invisibility of all but the white male, and the airbrushing out of any other Allied formations. It functions as a key tract in one strand of late-twentieth-century Australian nationalism: its anti-British sentiment. Weir's film tapped into popular Australian memory that the entire campaign can be attributed to systemic British bungling and incompetent leadership. ${ }^{83}$ It also functioned as a pivotal moment in transformation of the conservative Anzac Legend from its close association with the imperial ethos into a national story in which the British rather than the Turks (who are barely seen on screen) are identified as the real enemy. ${ }^{84}$ Weir's feature film is pre-eminent among three Australian screen texts made between 1980 and 1984 that were all inspired by radical nationalist understandings of Australian involvement - and its costs in fighting British wars. In so doing, they echoed the dominant reading of the 'post-imperial generation' in that country. ${ }^{85}$

Similarly, the Gallipoli experience provided a blueprint in Shadbolt's mind for a new, more confident nationalism that strove to assert the nation's mana. He also conceptualized the 1980s as a time when New Zealand was 'reconsidering traditional connections, and defying bullying allies', specifically Britain, France, the United States and even 'erstwhile fellow Anzacs' across the Tasman who were widely viewed by their smaller neighbours as pawns of American military power. Shadbolt was quite explicit that his objective was not only about telling New Zealand stories:

... the play - as I saw it then, and as it was to be later - is only ostensibly about New Zealand's fatal day on Chunuk Bair on August 8, 1915. It was really about New Zealanders - and New Zealand - seventy years on. Had it not been I should have interested myself in another project. ${ }^{86}$ 
New Zealand historians have noted that the upsurge of interest in Anzac Day during the 1980s revealed a popular belief that war and national identity were interconnected. This understanding was reflected in key external events such as the ANZUS crisis of 1985 as well as in an anti-nuclear consensus that would culminate in bi-partisan support for a nuclear-free New Zealand by 1989-90. ${ }^{87}$ At home the correlation between war and national identity was mirrored in the continuing output of books, plays and documentaries by Shadbolt, Pugsley and their contemporaries. ${ }^{88}$ At the same time, pacifist concerns of the 1960 s social movements were catapulted to mainstream consciousness by the 1980 s, symbolized by strong support for the Lange Labour government's rejection of American nuclear policy. Following close on the heels of Once on Chunuk Bair, Shadbolt became committed to the view that Gallipoli offered an important didactic lesson for contemporary New Zealanders; failure to confront the issues risked repeating the mistake of 'confining Gallipoli to a military-historical ghetto' and, ultimately, denying its meaning to the present. ${ }^{89}$

As with the auteur Peter Weir, an element of anti-Britishness cannot be decoupled from the nationalist treatise. Shadbolt draws on the mythology propagated by Hamilton and other commanders, and repeated by many scholars, that the August Offensive was a near miss, and that the New Zealanders - or more particularly the Wellingtons - were the key to Allied victory, had they only been reinforced at the critical moment rather than being let down by the insipid tea-drinking English at Suvla Bay and their incompetent commander, General Frederick Stopford. ${ }^{90} \mathrm{He}$ also restates the traditional view that Malone was killed by a shell from a British destroyer: according to Pugsley, it is more likely he was hit by New Zealand artillery. ${ }^{91}$ That said, Shadbolt nevertheless eschews the romantic sentimentality and sanitization that pervades Weir's text. The novelist-cum-dramatist instead opts for a gritty and unsentimental approach that foregrounds lice, flies, dysentery (the 'Gallipoli gallop' as he dubs it), and other atrocious conditions that plagued the men throughout 1915. Critics have also praised the strong and effective use of irony as a dramatic device and Shadbolt's skill at infusing dialogue with the distinctive New Zealand vernacular and humour. ${ }^{92}$ These elements combined to make the stage play a compelling piece of theatre when first performed at the Mercury Theatre in Auckland in $1982 .^{93}$

Both race and class boundaries are introduced in the text and are intended to be resolved as the drama reaches its catharsis. ${ }^{94}$ Perhaps the most contentious element of the play is its unreflexive restatement of traditional gender hierarchies at precisely the same historical moment that New Zealand society was being remade with growing recognition of plural identities constituting the body politic. There are two facets to this critique. The first concerns the text's interrelationship between masculinity and national identity - a restatement of orthodox historiography - at an historical juncture when a decolonizing New Zealand was scrutinizing its relationship with its erstwhile 'mother country'. A gendered dichotomy is constructed between a feminized, passive, tea drinking English leadership and regulars on the one hand and a masculinized filiality on the other that repeatedly harks back to the all-male communities delineated in Jock Phillips' A Man's Country? Moreover, the text articulates an obvious contempt for the maternal sexual behaviour that occasions a second betrayal: that is, the playwright aligns British abandonment of New Zealand in the 1970s with British betrayal of New Zealand soldiers on the heights of Chunuk Bair in August 1915. ${ }^{95}$

HARKNESS (shaken again): I still believe in it, sir.

CONNOLLY: In Homer?

HARKNESS: In the Empire, sir. Despite everything ... Sacrifice will be remembered, sir.

CONNOLLY: Sacrifice?

HARKNESS: I mean by the motherland, sir. 
CONNOLLY: Balls.

HARKNESS: Sir?

CONNOLLY: Mothers have been known to go whoring off for the highest price.

HARKNESS: Whoring off, sir?

CONNOLLY: Deserting their offspring, Harkness.

HARKNESS: We can't be forgotten - not altogether. Not altogether, sir.

CONNOLLY: Then, Harkness, we do even better ... ${ }^{96}$

The second dimension to this attempted 'remasculinization' of the nation can be detected in an unambiguous expression of traditional Pākehā male sexual identity at a time when fissures had opened up and traditional masculinity became subject to interrogation in a range of significant contemporaneous cultural texts, most notably in Greg McGhee's Foreskin's Lament. ${ }^{97}$

In 1991 Shadbolt's play was adapted as a feature film called simply Chunuk Bair. Unlike Weir's Gallipoli, a key film in the Australian revival that received the backing of a production company part owned by media magnate Rupert Murdoch, Chunuk Bair was made by a first time director, Dale Bradley, and was brought to the big screen on a shoestring budget without any support from key national screen agencies, the New Zealand Film Commission and New Zealand on Air. Gallipoli's production values were highly polished, it offered a superb evocation of the Australian landscape, and its dramatic qualities appealed very effectively to an international audience even if British critics objected to the film's ideology. ${ }^{98}$ In this sense Weir's screen text significantly overshadows its New Zealand equivalent. Yet for all of these apparent advantages Gallipoli is also a highly sentimental, romanticized and, at base, less honest rendition of Gallipoli mythology than is Chunuk Bair. Weir's film is a restatement of most key elements of the Anzac Legend, adding an antiBritish bias not evident in earlier visual texts whilst excising the traditional martial dimension of the legend. ${ }^{99}$ There is a continuity in Chunuk Bair's deployment of particular strands of Gallipoli mythology from the Shadbolt play, but it nevertheless manages some reinterpretation of old material by reference to fresh historical scholarship, notably Pugsley's 1984 book and that historian's passionate input as a key consultant to the production. The film also gets close to the heart of Connolly's dilemma (read William Malone) with its dramatic focus on his refusal of Johnston and Temperley's order that the Wellington Battalion advance on the summit of Chunuk Bair in what amounted to a suicide order. As outlined earlier, this moment was mostly hidden from history and constituted a key element of Malone's rehabilitation.

The technical deficiencies of Chunuk Bair and a failure to employ semiotic devices to successfully transpose the stage production to celluloid ensured that the feature film would not realize Maurice Shadbolt's ambition to create a fitting screen memorial to the bravery of the Wellington Battalion. The film relies mostly on very artificial studio-bound sets, there are problems with structure and lighting, the camerawork exults in its own amateurishness and the failure to build tension even at critical moments all work to weaken the impact of the screen text. One critic also commented on the narrative confusion of the screenplay in the first half. ${ }^{100}$ Overall, Chunuk Bair has the feel of a claustrophobic theatrical piece that does not successfully translate what was widely viewed as a powerful stage play on its debut into a celluloid production that relates a critical moment for New Zealand infantry in the campaign.

In conclusion, this article has focused on a key but transient phase of New Zealand cultural nationalism in the 1980s built on the edifice of Gallipoli and its bountiful tradition of myth making set against the backdrop of the country's external fissures and anxious transition into a postcolonial era. The key architect of this cultural moment was novelist, briefly-turned playwright Maurice Shadbolt whose interventions in history were synchronous 
with those of leading military historian Christopher Pugsley. Although the pattern and shifts in Anzac commemorative culture showed some broad similarities to Australia through the twentieth-century, there were nevertheless significant differences between the two countries in the construction of public memory and the cultural context in which popular historical mythology was constructed. Radical nationalist interpretations of Australian enmeshment in British wars resonated powerfully with the national psyche and this accounts for why screen texts on Anzacs were both pervasive and enduring. Although Shadbolt's nationalism was similarly inspired by the ideology of filial betrayal, on the other hand his nationalism was galvanized by a search for differentiation from an Australian identity. Furthermore, the circumstances surrounding the discrediting of Colonel William Malone's name provided a powerful and very particular ancillary motivation to Shadbolt who envisioned his work as part of a campaign to restore the honour of the fallen man. In that objective he was ultimately successful even though he would not live to see this moment. As illustrated, some critics have also pointed to his failure to address gender hierarchies in the text at a time of significant social change as evidence of an attempted remasculinization of the nation. However, to assert, as some have, that Shadbolt's play is just as guilty of distortion as Weir's screen text is difficult to sustain on the basis of the evidence outlined above. ${ }^{101}$

Histories of the campaign and related cultural productions have much to gain from comparative and transnational analyses as is already evident from the new revisionist scholarship and international documentaries of the early-twenty-first-century. ${ }^{102}$ Although at one level the strength of reaction to a tragedy of such epic proportions is perfectly understandable, for too long this episode has suffered from the blinkered gaze of nationalism that confines many depictions - especially but by no means exclusively the popular ones - to an historical ghetto riddled with parochial blind spots and omission of other stories of being an Anzac. ${ }^{103}$ In a trans-Tasman context there has been a greater tendency for this to happen in Australian writing and cultural productions on the campaign where the First World War remains ground zero for the collective memory of war and a culture of commemoration. The first decade of the new millennium has witnessed a clear shift in historical representations that make a critical attempt to situate the campaign in a more complex, holistic and, ultimately more truthful, way. How successful this trend will be in reinterpreting the campaign to a mass audience in the face of a populist, ahistorical juggernaut that valorizes heroism, sacrifice for the nation and nationalist sentiment, remains to be seen.

\footnotetext{
${ }^{1}$ I would like to extend my thanks to Stuart Macintyre, Annabel Cooper and Malcolm McKinnon for their valuable comments on earlier drafts of this paper, the audience of the Man Alone conference for their thoughtful questions and comments on its first iteration and to the two anonymous referees of the article.

${ }^{2}$ Bruce Babington, A History of the New Zealand Fiction Feature Film: Staunch As?, Manchester, 2007.

${ }^{3}$ Christopher Pugsley, On the Fringe of Hell: New Zealanders and Military Discipline in the First World War, Auckland, 1991, p.37.

${ }^{4}$ Maurice Shadbolt, Once on Chunuk Bair, Auckland, 1982. Chunuk Bair (directed by Dale Bradley, 1991). Maurice Shadbolt, Voices of Gallipoli, Auckland, 1988.

${ }^{5}$ See Annabel Cooper, 'Nation of Heroes, Nation of Men: Masculinity in Maurice Shadbolt's Once on Chunuk Bair', in Robin Law, Hugh Campbell and John Dolan, eds., Masculinities in Aotearoa/New Zealand, Palmerston North, 1999, pp.88-89.

${ }^{6}$ See Charlotte Caning, 'Feminist Performance as Feminist Historiography', Theatre Survey, 45, 2 (2004), pp.227-33.

As Philippa Mein Smith has argued, New Zealand and Australia have shared pasts but separate histories. The narrative of New Zealand and Australian soldiers and their encounters at war in 1915 is one of the best exemplifications of this point. See Philippa Mein Smith and Peter Hempenstall, 'Australia and New Zealand: Turning Shared Pasts into a Shared History', History Compass, 1 (2003), pp.1-8.

${ }^{8}$ Weir's Gallipoli is also widely considered to be the best Australian feature film yet made.

${ }^{9}$ The proliferation of Australian popular and scholarly work on the Great War and, for that matter, all overseas wars has dwarfed its New Zealand counterpart. Even allowing for the obvious disparity in size, Australian interest in this field - particularly before the 1980s - has been significantly greater. Conversely, there is a
} 
relatively rich literature on the New Zealand Wars unparalleled in Australia where conflict with indigenous peoples in the colonial era has never been officially recognized as warfare. Lake and Reynolds suggest that in no other country has overseas military experience been presented as so fundamental to a sense of national identity as in Australia. See Marilyn Lake and Henry Reynolds et al., What's Wrong with Anzac? The Militarisation of Australian History, Sydney, 2010, especially pp.22, 43,163. See Jenny McLeod, 'The Fall and Rise of Anzac Day: 1965 and 1990 Compared', War and Society, 20, 1 (2002), p.150.

${ }^{10}$ Lake and Reynolds; Joy Damousi, 'War and Commemoration: "The Responsibility of Empire", in Deryck M. Schreuder and Stuart Ward, eds., Australia's Empire, Oxford, 2010, p.310.

${ }^{11}$ See for example: Alistair Thompson, "'Steadfast until Death?": C.E.W. Bean and the Representation of Australian Military Manhood', Australian Historical Studies, 23, 93 (1989), pp.462-78; D.E. Kent, 'The Anzac Book and the Anzac Legend: C.E.W. Bean as Editor and Image-Maker', Historical Studies, 21 (1985), pp.37690; L.L. Robson, 'The Origin and Character of the First AIF: 1914-1918: Some Statistical Evidence', Historical Studies, 15 (1973), pp.737-49; Robin Gerster, Big-noting: The Heroic Theme in Australian War Writing, Melbourne, 1987.

${ }^{12}$ McLeod, p.162.

${ }^{13}$ T.H.E. Travers, 'Gallipoli: Film and the Traditions of Australian History', Film and History, 14, 1 (1984), pp.15-18 and Jonathan Rayner, The Films of Peter Weir, $2^{\text {nd }}$ ed, New York, 2003, p.90.

${ }^{14}$ Jenny Macleod, 'Beckham, Waugh and the Memory of Gallipoli', in John Crawford and Ian McGibbon, eds., New Zealand's Great War: New Zealand, the Allies \& the Great War, Auckland, 2007, pp.146-47.

${ }^{15}$ See Jeffrey Grey, 'Military History and Historians', in Ian McGibbon, ed., The Oxford Companion to New Zealand Military History, Auckland, 2000, pp.321-23.

${ }^{16}$ See James Bennett, “"Massey's Sunday School Picnic Party”: “The Other Anzacs” or Honorary Australians?', War and Society, 21, 2 (2003), pp.23-54.

${ }^{17}$ See Jock Phillips, A Man's Country? The Image of the Pākehā Male: A History, Auckland, 1996, p.165.

${ }^{18}$ See Bill Gammage, 'Truth and Tradition in Australia, New Zealand and Papua New Guinea', in John A. Moses, ed., Historical Disciplines and Culture in Australasia. An Assessment, Brisbane, 1979, especially pp.4647.

${ }^{19}$ The lemon squeezer is an innovation that can be credited to William Malone. See John Crawford with Peter Cooke, eds., No Better Death: The Great War Diaries and Letters of William G. Malone, Auckland, 2005.

${ }^{20}$ Shadbolt was very conscious of this issue. See Maurice Shadbolt Papers, 91-047-17/05, Correspondence, notes on Gallipoli project, 23 June 1982, Alexander Turnbull Library (ATL), Wellington.

${ }^{21}$ See Nicholas Boyack, Behind the Lines: The Lives of New Zealand Soldiers in the First World War, Wellington, 1989; Jock Phillips, Nicholas Boyack and E.P. Malone, eds., The Great Adventure, Wellington, 1988; Bennett, pp.23-54.

${ }^{22}$ For a discussion of the 'formal and the folkloric' in the Australian Anzac tradition see Graham Seal, Inventing Anzac: The Digger and National Mythology, Brisbane, 2004, especially pp.1-9.

${ }^{23}$ See for example Allen to Birdwood, 26 October 1915, Allen Papers, 1912-1919, Box 9, Miscellaneous files and correspondence, National Archives (New Zealand).

${ }^{24}$ That frustration is captured in the following comment by Shadbolt: 'For fifty years a curious and tactful silence was preserved, with survivors of Chunuk Bair too cowed and dispirited to talk of it other than among themselves, and then furtively, at reunions.' See Voices of Gallipoli, p.118.

${ }^{25}$ Boyack, pp.56, 59, 61. The fall of Singapore and the capture of 16,000 Australian infantry by Japanese forces in February 1942 compounded the suspicion of Churchill. One New Zealand historian has demonstrated that Singapore perpetuated the dominant Australian narrative of failed British leadership in war. New Zealand reactions differed and a controversy erupted involving the Wellington Mayor, T.C.A. Hislop, whose spirited defence of Churchill embroiled him in a 'trans-Tasman mudslinging match'. See Glyn Harper, 'Threat Perception and Politics: The Deployment of Australian and New Zealand Ground Forces in the Second World War', Journal of the Australian War Memorial, 20 (1992), p.41; Damousi, pp.303-4, and Stuart Macintyre, A Concise History of Australia, Cambridge, 1999, p.188.

${ }^{26}$ Tara Brabazon argues that, at an official level, Gallipoli had a fracturing rather than a unifying effect on relations between Australia and New Zealand. That fissure was symbolized by contrasting responses to the Union Jack. As supporting evidence she cites the case of the 'Body-line' Ashes tour of Australia in 1932-33 by the England cricket team: rather than eliciting a show of Antipodean unity against the inflammatory tactics of England players in the series, the cricketers were instead given a very enthusiastic reception when they arrived in New Zealand. See Tara Brabazon, Tracking the Jack: A Retracing of the Antipodes, Sydney, 2000, pp.24-27. ${ }^{27}$ Graeme Hunt, 'The Folly \& The Glory', New Zealand Listener, 14 May 2005, p.19.

${ }^{28}$ Harvey Broadbent, Gallipoli: The Fatal Shore, Melbourne, 2000, p.204; Les Carlyon, Gallipoli, Sydney, 2001, p.410. See Ray Grover, 'Johnston, Brigadier-General Francis Earl', in McGibbon, ed., The Oxford Companion to New Zealand Military History, p.260. 
${ }^{29}$ James Belich, Paradise Reforged: A History of the New Zealanders from the 1880s to the Year 2000, Auckland, 2001, p.97.

${ }^{30}$ Chris Pugsley, 'Stories of Anzac', in Jenny McLeod, ed., Gallipoli: Making History, London, 2004, p.47.

${ }^{31}$ See Gerster, especially p.19.

${ }^{32}$ K.S. Inglis and Jock Phillips, 'War Memorials in Australia and New Zealand: A Comparative Survey', in John Rickard and Peter Spearritt, eds., Packaging the Past? Public Histories, Melbourne, 1991, especially p.186, 189-91. Inglis and Phillips observe that the ideological utility of 1914-1918 war memorials in Australia was to honour those diggers who served and to sub-textually dishonour the 'malingerers' who evaded their duty. Also see Chris Maclean and Jock Phillips, The Sorrow and the Pride: New Zealand War Memorials, Wellington, 1990, p.108.

${ }^{33}$ See Crawford, ed., No Better Death, p.363, n.51.

${ }^{34}$ Maurice Shadbolt Papers, 91-047-17/05, Correspondence, Notes on Gallipoli project, 23 June 1982, ATL, Wellington.

35 Daniel Reynaud, Celluloid Anzacs: The Great War through Australian Cinema, Melbourne: Australian Scholarly Publishing, 2007.

${ }^{36}$ James Curran and Stuart Ward, The Unknown Nation: Australia after Empire, Melbourne, 2010, pp.8-9, 1516, 247-48, 254-55.

${ }^{37}$ Ibid., pp.197-99.

${ }^{38}$ Belich, p.392.

${ }^{39}$ Ibid., esp. part 5.

${ }^{40}$ Ibid., p.392

${ }^{41}$ Ibid., p.30.

${ }^{42}$ Ibid., pp.36, 56. Deryck M. Schreuder and Stuart Ward, 'Epilogue: After Empire', in Schreuder and Ward, eds., Australia's Empire, p.394.

${ }^{43}$ Ian Conrich and Stuart Murray, 'Introduction', in Ian Conrich and Stuart Murray, eds., Contemporary New Zealand Cinema: From New Wave to Blockbuster, London, 2008, p.2.

${ }^{44}$ The Australian Film Development Corporation was replaced in 1975 by the Australian Film Commission. Conrich and Murray, pp.5, 10.

${ }^{45}$ Cherie Lacey, 'Unsettled Historiography: Postcolonial Anxiety and the Burden of the Past in Pictures', in Alistair Fox, Barry Keith Grant and Hilary Radner, eds., New Zealand Cinema: Interpreting the Past, Bristol, 2011, pp.99-118. The preponderance of chapters in this collection on film addressing the colonial past and Maori- Pākehā relations is striking though not surprising given the key concerns of New Zealand filmmakers.

${ }^{46}$ Maclean and Phillips note that the period from 1872 to 1902 was marked by an amnesia in relation to the New Zealand Wars. When new memorials to the Wars began to be constructed again in the period 1907 to 1920, the major catalyst for this new construction program was imperialistic feeling generated by the war in South Africa. See Maclean and Phillips, pp.25-30.

${ }^{47}$ Stuart Murray, “'Precarious Adulthood"; Communal Anxieties in 1980s Film', in Conrich and Murray, eds., Contemporary New Zealand Cinema, p.178

${ }^{48}$ Geraldene Peters, 'Patu!', in James Bennett and Rebecca Beirne, eds., Making Film and Television Histories: Australia and New Zealand (London; New York, 2012), p.46; Belich, esp. pp.518-19.

${ }^{49}$ Cooper, p.87.

${ }^{50}$ Judith Dale, 'Interrogating Identity in New Zealand Stage Plays', in Andrew Benjamin, Tony Davies, Robbie B.H. Goh, eds., Postcolonial Cultures and Literatures: Modernity and the (Un)Commonwealth, New York, 2002, p.322. Melvyn Thompson, 'review of Maurice Shadbolt, Once on Chunuk Bair', Australasian Drama Studies, 2, 2 (1984), pp.118-20.

${ }_{51}$ Catriona Elder, Being Australian: Narratives of National Identity, Sydney, 2007, p.52.

${ }^{52}$ Susan Dermody and Elizabeth Jacka, The Screening of Australia, Volume 2: Anatomy of a National Cinema, Sydney, 1988, p.163.

${ }^{53}$ Ann Curthoys, Expulsion, Exodus and Exile in White Australian Historical Mythology', Journal of Australian Studies, 23, 61 (1999), pp.2-3, 10-12.

${ }^{54}$ P. Maunder and Amamus Theatre Group, Gallipoli - An Evocation, 1996. Unpublished manuscript, contact Playmarket, P.O. Box 9767, Wellington, New Zealand.

${ }^{55}$ See for example O.E. Burton, The Silent Division: New Zealanders at the Front 1914-1919, Sydney, 1935, p.316, Keith Sinclair, A History of New Zealand, Auckland, 1988, pp.232-33; W.P. Morrell, New Zealand, London, 1935. For a feminist critique of the enmeshment of masculinity with national identity in Australia, see for example Patricia Grimshaw, Marilyn Lake, Ann McGrath, Marian Quartly, Creating a Nation, Melbourne, 1996, p.218, and Marilyn Lake, 'Mission Impossible: How Men Gave Birth to the Australian Nation Nationalism, Gender and Other Seminal Acts', Gender and History, 4, 3 (1992), pp.305-22.

${ }^{56}$ Maunder and Amamus Theatre Group. 
${ }^{57}$ Marc Maufort and David O'Donnell, Performing Aotearoa: New Zealand Theatre and Drama in an Age of Transition, Brussels, 2007, pp.59-64.

${ }^{58}$ Maurice Shadbolt, The Lovelock Version, London, 1980; Shadbolt, Once on Chunuk Bair; Shadbolt, Voices of Gallipoli.

${ }^{59}$ Peter Weir in Celluloid Heroes, episode 4 (Film Australia, 1995).

${ }^{60}$ Shadbolt, Voices of Gallipoli, pp.7-10.

${ }^{61}$ Ibid., pp. 7, 9,10. Pugsley deems Temperley's views to be both 'unfair' and inaccurate'. See Pugsley, Gallipoli, pp.287-88.

${ }^{62}$ Christopher Pugsley, Gallipoli.: The New Zealand Story, Auckland, 1984, p.291.

${ }^{63}$ Ibid., p.282. Crawford, ed., No Better Death, p.307.

${ }^{64}$ Colonel A.C. Temperley, Personal Narrative of the Battle of Chunk Bair 6-10 August 1915, pp.1, 11-13, 15, 24, accession no. 1994.3315, QEII Army Memorial Museum, Waiouru. For details of Malone's military background and extensive knowledge of military subjects, see Crawford, ed., No Better Death, especially pp.3437, 319. On the issue of siting trenches on the crest of Chunuk Bair, see especially pp.313-14.

${ }^{65}$ See Pugsley, Gallipoli, p.282; John North, Gallipoli: The Fading Vision, London, 1966, pp.115-16; Major Fred Waite, The New Zealanders at Gallipoli, Auckland, 1919, p.237; C.E.W. Bean, The Story of Anzac: From 4 May, 1915, to the Evacuation of the Gallipoli Peninsula, Sydney, 1939, especially pp.671, 680. Temperley's narrative also influenced the British official history. See Cecil Malthus, Anzac: A Retrospect, Christchurch, 1965, p.106.

${ }^{66}$ Waite, p.221.

${ }^{67}$ Crawford, ed., No Better Death, p.337.

${ }^{68}$ Robert Rhodes James, Gallipoli, Sydney, 1965, p.285.

${ }^{69}$ Crawford, ed., No Better Death, pp.337-38.

${ }^{70}$ For details of other assault columns in the August Offensive, their leadership, structure and military objectives see Broadbent, pp.190-91.

${ }^{71}$ Temperley reveals in his own personal narrative that he was well aware Johnston was sick (as others also knew) and was no longer fit to command. He claimed that 'disloyalty' prevented him from informing superiors of Johnston's true condition. Johnston also used alcohol to relieve his physical and mental condition, and it has been conjectured that this compounded his lack of judgment in the battle for Chunuk Bair. See Colonel A.C. Temperley, Personal Narrative of the Battle of Chunk Bair 6-10 August, 1915, pp.18-19, accession no. 1994.3315, QEII Army Memorial Museum, Waiouru. Also see Carlyon, p.437; R. James, Gallipoli, London, 1965; Crawford, ed., No Better Death, p.307; McGibbon, ed., 'Johnston, Brigadier-General F.E.', p.260. For Malone's refusal see Glyn Harper and Colin Richardson, In the Face of the Enemy, Auckland, 2006, p.83. It is evident from Malone's diary that he did not trust Temperley, referring to him in May 1915 as a "poisonous" sneak', and that Johnston and Temperley were not used to, and disliked, Malone having an independent opinion. See Crawford, ed., No Better Death, especially pp.202, 261.

${ }_{72}^{72}$ Pugsley, Gallipoli, pp.286-87, 308. Crawford, ed., No Better Death, p.308.

${ }^{73}$ Crawford, ed., No Better Death. forewords by Rt. Hon Helen Clark and Air Marshal Bruce Ferguson, and pp.21, 37, 39, 325. Crawford's book was launched by Helen Clark on the $90^{\text {th }}$ anniversary of the Gallipoli campaign. As both Prime Minister and Minister for Culture and Heritage, Clark sought to strengthen a sense of national identity and Anzac Day was a key vehicle for that project. She actively fostered Anzac Day and the annual ceremony at Anzac Cove.

${ }^{74}$ Ibid., p.21.

${ }^{75}$ Cooper, p. 95 .

${ }^{76}$ See Crawford, ed., No Better Death, pp.163, 179-80, 233, 268, 276, 283 and Bennett, pp.35-45.

${ }^{77}$ See Crawford, ed., No Better Death, especially pp.263, 276.

${ }^{78}$ Shadbolt, Once on Chunuk Bair, p.76.

${ }^{79}$ Four Corners, ABC Television (reporter Chris Masters), 'The Great History Wars', 10 November 2008. http://www.abc.net.au/4corners/content/2008/s2411881.htm, accessed 30 August 2011.

${ }^{80}$ Oral history methodology has advanced considerably in the past few decades. Whilst reliability of memory is still an issue to be aware of, many oral historians today are just as interested in what people believe to have been true regardless of its basis in fact.

${ }^{81}$ Shadbolt, Voices of Gallipoli, pp.10-15.

${ }^{82}$ Ibid., p. 15 .

${ }^{83}$ Australian denunciations of British leadership on the Gallipoli peninsula have a long lineage that can be traced back to Australian-born war correspondent Keith Murdoch who emphasized Australian fighting qualities while condemning British leaders for their bungling. See Macintyre, p.158.

${ }^{84}$ Curran and Ward, pp.247-48. 
${ }^{85}$ Damousi, pp.307-9. The other two examples were Bruce Bereford's Breaker Morant (1980) on the Boer War and the television mini-series The Last Bastion (1984) on the Second World War.

${ }^{86}$ Shadbolt, Voices of Gallipoli, p.122; Phillip Mann, 'The First Production of Once on Chunuk Bair: An Interview with Maurice Shadbolt', Illusions, 11 (1989), p.15.

${ }^{87}$ The National Party's acceptance of the nuclear-free policy was at first on a de facto basis.

${ }^{88}$ Ian McGibbon, 'Anzac Day', in McGibbon, ed., The Oxford Companion to New Zealand Military History, p.30.

${ }^{89}$ Maurice Shadbolt Papers, 91-047-17/05, Correspondence, notes on Gallipoli project, 23 June 1982, ATL, Wellington.

${ }^{90}$ See for example Michael Neill, 'Introduction: Getting Out from Under', in Shadbolt, Once on Chunuk Bair, p.11; Shadbolt, Once on Chunuk Bair, pp.85, 96; and Shadbolt, Voices of Gallipoli, pp.114-15. Pinning the blame for the failure of the Suvla Bay operation in early August on Stopford was a convenient diversionary tool used by the British military leadership from Birdwood down and is a feature of Australian narratives of Gallipoli from Bean to Weir's Gallipoli with its insistence on tying Suvla Bay to the Australian diversion at the Nek. In truth the objectives of the Suvla Bay operation shifted over time - partly based on Stopford's critique of his superiors' unrealistic goals. In the final analysis, the major objective of the Suvla landings was to establish it as a base for reinforcements. Any assistance that might later be afforded to Anzacs on the Sari Bair range was a desirable but ancillary objective only. See Robin Prior, Gallipoli: The End of the Myth, Sydney, 2009, pp.207-9; Robin Prior, 'The Suvla Bay Tea-Party: A Reassessment', Journal of the Australian War Memorial, 7 (1985), pp.25-34; and Rhys Crawley, 'The Myths of August at Gallipoli' in Craig Stockings, ed., Zombie Myths of Australian Military History, Sydney, 2010, pp.50-69. Shadbolt's inflated claim of the significance of New Zealanders and their brief seizure of Chunuk Bair has already been noted. See Donald Denoon, Philippa Mein Smith with Marivic Wyndham, A History of Australia, New Zealand and the Pacific, Oxford, 2000, p.277.

${ }^{91}$ Cf. Shadbolt, Chunuk Bair, pp.99-100 and historian Keith Sinclair, A Destiny Apart, New Zealand's Search for a National Identity, Wellington, 1986, p.161 and Phillips, Boyack and Malone, eds., The Great Adventure, p.68 with Chris Pugsley, The Anzac Experience: New Zealand, Australia and Empire in the First World War, Auckland, 2004, p.106 and Chris Pugsley. 'Malone, William George - Biography', from the Dictionary of New Zealand Biography. Te Ara - the Encyclopedia of New Zealand, updated 1September 2010 URL: http://www.TeAra.govt.nz/en/biographies/3m40/1, accessed 12 October 2011.

${ }^{92}$ See for example Philip Mann, 'Maurice Shadbolt the Dramatist: On the Dramaturgy of Once on Chunuk Bair' in Ralph J. Crane, ed., Ending the Silences: Critical Essays on the Works of Maurice Shadbolt, Auckland, 1995, p.137, and Neill, 'Introduction: Getting out from Under', in Shadbolt, Once on Chunuk Bair, p.14.

${ }^{93}$ See J.C. Ross, 'Review of Maurice Shadbolt, Once on Chunuk Bair', Landfall, 37, 2 (1983), p.240.

${ }^{94}$ Dale, p.326. On the class issues embedded in the play, see Melvyn Thompson, , pp.118-20.

${ }^{95}$ See Cooper, pp.94-97; Dale, pp.322-23.

${ }^{96}$ Shadbolt, Once on Chunuk Bair, pp.84-85.

${ }^{97}$ Cooper, especially pp.96-99. Dale, , pp.331-32.

${ }^{98}$ See for example Stuart Ward, "“A War Memorial in Celluloid”: The Gallipoli Legend in Australian Cinema, 1940s-1980s', in Jenny McLeod, ed., Gallipoli: Making History, New York, 2004, p.71 and Richard Leonard, Mystical Gaze of the Cinema: The Films of Peter Weir, Melbourne, 2009, p.187.

${ }^{99}$ Ward, 'A War Memorial in Celluloid', pp.65-66.

${ }^{100}$ Brian McDonnell, 'Chunuk Bair', in On Reflection: New Zealand Film Reviews from North and South, 19861993, London, 2007, p.48. Also see John Parker, 'Review of Chunuk Bair', Metro, 130 (1992), p.143.

${ }^{101}$ Denoon, Mein Smith with Wyndham, p.277.

${ }^{102}$ For revisionist scholarship see in particular Tim Travers, Gallipoli 1915, Stroud, 2001; Broadbent,; Peter Stanley, Quinn's Post, Anzac, Gallipoli. Sydney, 2005 and Prior, Gallipoli: The End of the Myth. For documentaries see Gallipoli: The Frontline Experience (directed by Tolga Örnek, 2005) and Revealing Gallipoli (directed by Wain Fimeri, 2005).

${ }^{103}$ For a discussion of this point in relation to Australia see Elder, pp.249-51. 